\title{
'Normal' Emeğin Kırılganlığı ve Eşitlenme: Eve Sığmayan Hayatlar ve Pandemide Seks İş̧ileri Belgesellerini Prekarya Üzerinden Düşünmek
}

\author{
KAAN AKIN ${ }^{1}$, ÇAĞDAŞ DUMAN ${ }^{2}$ \\ ${ }^{1}$ PhD Candidate, Hacettepe University, Institute of Social Sciences, Communication \\ Sciences PhD Program (Orcid ID: 0000-0002-3578-6205) \\ ${ }^{2}$ PhD Candidate, Boğaziçi University, Institute of Social Sciences, English Literature PhD \\ Program (Orcid ID: 0000-0002-8330-2965)
}

\section{Özet}

Bu çalışmada her ikisi de pandemi döneminde çekilmiş ve çevrimiçi platformlarda gösterilmiş olan, Eve Sığmayan Hayatlar (Sertaç Yıldız, 2020) ve Pandemide Seks Iş̧̧ileri (Ayşe Adanalı ve Volkan Işıl, 2020) isimli belgeseller ile birlikte, bir sınıf olarak prekarya ve onun beraberinde getirdiği güvencesizlik, kırılganlık, belirsizlik ve düzensizlik kavramları incelenmektedir. Makalenin amacı, filmlerde Judith Butler'ın "kaçınılmaz bağımlılıklar" olarak tarif ettiği ortaklıkları keşfetmektir. Her iki film birlikte düşünüldüğünde kurulan ortaklıklar, bize kırılganlıkları eşitlenme açısından düşünme olanağı verir. Ayrıca, prekaryadan ve varoluşsal güvencesizlikten bahsedilirken seks işçilerinden söz edilmemesi, alanda hâlâ bir boşluk olduğuna işaret etmektedir. Eşitlenme deneyimleri göz önünde bulundurulduğunda, belgesellerdeki seks işçileri, kurye, bankacı, hemşire ve market çalışanının her ne kadar aynı oranda olmasa da tüm kırılganlıklarının ekrana yansıdığı görülür. Sanatın pandemi koşullarında güvencesini kaybedenlere ya da zaten hâlihazırda güvencesiz olanlara görünürlük sağladığını söylemek yanlış olmayacaktır. Özellikle, pandemi döneminde tekrardan gündeme gelen iş̧̧i hakları ve/ya hak kayıpları göz önünde bulundurulduğunda, incelenen belgeseller bizi emeğin tanımını yeniden düşünmeye çağırır.

Anahtar Kelimeler: belgesel, eşitlenme, Covid-19, kırılganlık, prekarya 


\title{
Precariousness of 'Normalized' Labor and
}

\section{Equalisation: Eve Sığmayan Hayatlar (Lives That Don't 'Fit into' Home) and Pandemide Seks Işçileri (Sex Workers in the Pandemic)}

\begin{abstract}
This study examines documentaries Eve Siğmayan Hayatlar (Lives That Don't 'Fit into' Home, Sertaç Yıldız, 2020) and Pandemide Seks Iş̧̧ileri (Sex Workers in the Pandemic, Ayşe Adanalı and Volkan Işı|, 2020), both of which were shot during the pandemic period and shown on online platforms, within the framework of precaria as a class and related terms such as insecurity, vulnerability, uncertainty and disorder. The aim of this article is to explore reciprocal concerns by pointing to the "inevitable interdependencies" in these films. When these two films are considered together, the parallels allow us to think about vulnerabilities in terms of equalization. In addition, the fact that there is no mention of sex workers with regard to precariat and existential insecurity still points to a gap in the field. Considering the experiences of equalization; sex workers, couriers, bankers, nurses and grocery workers in the documentaries, albeit not proportionately, reflect all their vulnerabilities on the screen. It is possible to say that art offers visibility for those who have lost their security in pandemic conditions as well as for those who are already insecure. In particular, given the labor rights and/or the loss of rights that come up again during the pandemic period, the documentaries examined call on us to reconsider the definition of labor.
\end{abstract}

Keywords: documentary, equalisation, Covid-19, vulnerability, precaria

Corresponding Author / Sorumlu Yazar

Manuscript Received / Gönderim Tarihi

Revised Manuscript Accepted / Kabul Tarihi

To Cite This Article / Kaynak Göster

\section{KAAN AKIN}

Hacettepe University, Institute of Social Sciences,

Communication Sciences PhD Program

akinnkaan@gmail.com

February 1, 2021/ 1 Şubat 2021

May 9, 2021 / 9 Mayıs 2021

Akın, K. \& Duman, Ç (2021). 'Normal' Emeğin Kırılganlı̆̆ı ve Eşitlenme: Eve Sığmayan Hayatlar ve Pandemide Seks Isş̧ileri Belgesellerini Prekarya Üzerinden Düşünmek. ViraVerita E-Journal: Interdisciplinary Encounters, Vol.13, 209-234. 


\section{'Normal' Emeğin Kırılganlığı ve Eşitlenme: Eve Sığmayan Hayatlar ve Pandemide Seks İşçileri Belgesellerini Prekarya Üzerinden Düşünmek}

\section{Giriş}

Neredeyse herkesin kendi normunu sorguladığı bugünlerde, kuşkusuz ki birçok çalışanın kırılganlıkları sadece ülke sınırları içerisinde değil, Covid-19 salgınının görüldüğü tüm dünya ülkelerinde arttı. İş̧̧i haklarını son zamanlarda yeniden tartışmaya açan çalışmalar da tekrardan gündeme geldi. Bu çalışmalardan birinde, Guy Standing prekarya tanımını işçi sınıfının deneyimlediği kırılganlığı ön plana taşıyarak ele almıştır. Standing Prekarya: Yeni Tehlikeli Sınıf (2011) adlı kitabında, prekarya teriminin günümüz kapitalist toplumlarındaki işçi sınıfına (proletarya) kırılgan sıfatının (precarious) eklenmesiyle ortaya çıktığından bahseder (s. 7). Hem iş̧̧i sınıfı mücadelesinin kapsamını genişletmek, hem de sınıfın yaşadığı hak kayıplarının altını çizmek Standing'in amaçları arasındadır. Kavramların Türkçedeki karşılıklarına bakıldığında, Elif Demirkaya "Prekarlık ve Prekarite Tartışmalarına Kısa Bir Giriş" (2017) başlıklı makalesinde prekarizasyon ve prekarya tanımlarına şu şekilde açıklık getirmiştir: "Precarization, bilhassa çalışma koşullarının güvencesizliğine vurgu yapmak suretiyle, emek literatüründe güvencesizleştirme olarak geçer. Precariat ise prekarya olarak Türkçeye yerleşmiştir. Sözleşmeli, yarı zamanlı, kayıt dışı çalışanlar, geçici işlerle günü kurtaranlar, bilişsel emekçiler, mülteciler ve işsizler prekarya kapsamında değerlendirilmektedir" (s. 6).

Bu yazıda her ikisi de pandemi döneminde çekilmiş ve çevrimiçi platformlarda gösterilmiş olan, Eve Sığmayan Hayatlar (Sertaç Yıldız, 2020) ve Pandemide Seks Iş̧̧ileri (Ayşe Adanalı ve Volkan Işıl, 2020) isimli belgeseller ile birlikte, bir sınıf olarak prekarya ve onun beraberinde getirdiği güvencesizlik, kırılganlık, belirsizlik ve düzensizlik kavramları incelenmektedir. Denilebilir ki, Eve Sığmayan Hayatlar ve Pandemide Seks Iş̧̧ileri filmleri birlikte düşünüldüğünde, anlatılar 'normalde' var olan kırılganlıkların ve güvencesizliklerin pandemi koşullarında daha da arttığını gösterir. Ayrıca, düzcinsellerin baskın olarak bulunduğu iş kollarındaki kırılganlığın, kuir / trans varoluşları ile paralel olarak okunabilmesi mümkün hale gelmiştir. Eşitlenme deneyimleri göz önünde bulundurulduğunda, belgesellerdeki seks iş̧̧ileri, kurye, bankacı, hemşire ve market çalışanı her ne kadar aynı oranda olmasa da tüm kırılganlıklarını ekrana yansıtmışlardır. Özellikle, pandemi döneminde tekrardan gündeme 
gelen işçi hakları ve/ya hak kayıpları göz önünde bulundurulduğunda, incelenen belgeseller bizi emeğin tanımını yeniden düşünmeye çağııır.

Makalenin birinci bölümünde Guy Standing'in sosyo-ekonomik bir sınıf olarak tanımladığı prekarya kavramını ele alınacaktır. Daha sonra, kırılganlık (precariousness) üzerine daha varoluşsal bir tartışma sunan Judith Butler ve Isabell Lorey'in fikirlerine değinilecektir. İkinci bölümde, Sertaç Yıldız’ın Eve Sığmayan Hayatlar belgeseli, prekarya ve kırılganlık çerçevesinde ele alınacaktır. Son bölümde ise Ayşe Adanalı ve Volkan Işı|'ın yönettiği Pandemide Seks Iş̧̧ileri belgeseli yine benzer kavramlarla ve seks iş̧̧iliğini ele alan literatürden hareketle tartışılacaktır. Sonuç bölümünde ise, filmlerin bize birinci ağızdan aktardığı pandemi sürecinde açığa çıkan ya da derinleşen kırılganlıklarının, "normal”i nasıl değiştirdiği, işçi haklarının sınırlarının nasıl genişletilebileceği hakkında bir tartışma yürütülecektir. Bunun önemini, Hannah DeLacey şu şekilde açıklar: "Covid-19 salgını, dünyanın en savunmasız kesimleri üzerinde en büyük etkiye sahip akıl almaz bir trajedidir, ancak toplumu yeniden düşünmek ve yaşam kalitesini artırmak ve insan haklarını korumak için politikaları yeniden şekillendirmek için bir fırsat olabilir" (2020).

\section{"Yeni Tehlikeli Sınıf" Prekarya ve Kırılganlık}

Dijitalleşme süreçleri ve kapitalist ekonomik düzenin baskın olduğu ülkelerin politikaları ile birlikte, emeğin tanımlanması ve maddileştirilmesinde değişiklikler olmuştur. Esnek çalışma saatleri, birden fazla işi aynı kişinin üstlenmesi, performans ve hizmet puanları, gelecekle ilgili önünü görememe, kariyerinde ilerleyememe gibi durumlar emek üzerine yapılan tartışmaları çok boyutlu bir biçimde ele almamızı sağlamıştır.

Bu değişimi günümüzde dile getiren ve kavramsallaştıran Britanyalı sosyolojist Guy Standing olmuştur. Standing, Prekarya: Yeni Tehlikeli Sınıf (2011) kitabında, gelecekleri ellerinden alınan ve toplumsal kolektif hafızaya dâhil edil(e)meyen işçileri ele alır. İş ve gelir güvencesizliğinin yanı sıra, prekaryanın iş̧̧i kimliğinden mahrum olduğunun, çalışma hayatlarında kariyer yapabilmesinin zorlaştığının altını çizer (Standing, 2011, s. 12). Bu da, herhangi bir işçi topluluğuna ait hissedememe ve ardından yalnızlaşma ve işçi haklarından soyutlanmayı getirmektedir. Ayrıca, yine Standing'e göre prekarya, sınıf temelli bir oluşumdan daha katmanlı bir yapıya sahiptir: "Tarih boyunca bütün önemli hareketler, iyi ya da kötü, sınıf temelliydi. Bir ya da birkaç grup, kendisini sömüren ya da kendisine zulmeden başka bir grupla 
mücadele etmişti" (Standing, 2011, s. 13). Ancak prekaryadan bahsederken, böyle bir sınıf bilincinden bahsetmek pek de mümkün olmamaktadır çünkü prekarya içerisindeki bileşenler sınıf temelli ayrımcılığın ötesindedir. Standing, prekarya tartışmalarını Prekarya Bildirgesi: Hakların Kısılmasından Yurttaşlığa (2017) kitabında devam ettirir. Hak temelli bir tartışma çerçevesinde Standing, birçok vatandaşın (citizen) kısmi vatandaşlara (denizen) dönüşerek temel haklarından mahrum bırakıldığının altını çizer (Standing, 2017, s. 20). Bu kısmi vatandaşlık, sadece göçe bağlı değildir ve neoliberalizmin "kademeli üyeliğe" dayanan toplum modelinin bir yansımasıdır (Standing, 2017, s. 20). Yurttaşlığın tam olabilmesi için, Standing bu kitabında da hak temelli politikalarından bahseder. Genel olarak bakıldığında her iki kitabında da Standing, güvencesizliğin getirdiği hak kayıplarından ve bu hakların nasıl geri kazanabileceği üzerinden tartışmalar yürütür.

Standing'in daha kapsayıcı oluşmakta-olan iş̧̧i sınıfı (a class-in-the-making) tanımı prekarya, birkaç yönden önemli eleştiriler almıştır. Richard Saymour (2012) kırılganlığın her kesimde aynı şekilde hissedilmediğinden ve çalışanların farklı kırılganlık seviyelerinden bahsederek sınıflar arası farklılı̆ın altını çizer. Bu fikre paralel olarak Jan Breman (2013), gayrı resmi / kırılgan birçok emek çeşidi olduğunu ve bunların hepsinin aynı oranda 'tehlike' yaratmadığını savunur. Peter Frase bir sınıf kategorisi olarak prekaryayı sorunlu bulduğunu, tanımın "nüfusun çok fazla farklı heterojen tabakalarını bir araya getirmeye çalıştığını" belirtir (2013, s. 11). Tüm bu eleştirilere bakıldığında, belki de prekarya yeni bir sınıf yaratma potansiyelinden yoksundur. Ancak bunun karşısında Maribel Casas-Cortez'in savunduğu gibi, prekaryanın "dünyayı sabitlenmemiş bir algılama biçimi geliştirecek ve tekillikleri bağlamanın potansiyelini vurgulayan bir araç olarak" (2014, s. 222-23) işe yaradığından bahsetmek de aynı derecede mümkündür. Diğer bir deyişle, çeşitli emek biçimleri ve güvencesizlikler arasında ortaklıklar kurmada, prekarya şemsiye terim olarak kullanılabilmektedir. Ekonomik ve sosyal kategoriler üstü bir birleşmeden söz edildiğinde, burada bir dayanışma ağı oluşabilmektedir. Standing her ne kadar yeni sınıf tanımını eleştiriye açık bir şekilde genellemiş olsa da, kırılganlık ve güvencesiz emek üzerine söyledikleri dikkat çekicidir ve günümüz toplumlarının durumunu analiz etmek bakımından elverişli olabilmektedir. Standing'in bu tanımlamalarına, özellikle Eve Sığmayan Hayatlar'ı incelerken geri dönülecektir.

Ulusal sınırlar içerisinde de, prekarya tartışmaları güncelliğini korumaktadır. Aralık 2009'da Tekel işçilerinin başlattığı grevle adından daha çok söz ettiren prekarite üzerine Tanıl Bora, "Tekel Direnişinde Ara Son-Sınıf Mücadelesi" (2010) başıklı denemeyi kaleme almıştır. 
Bu yazıda Bora, prekaryayı "[z]amanımızın proleteryası" olarak tanımlamaktadır: "Güvencesiz, keyfi şartlarda çalıştırılan, kronik geçici işlere mahkûm, bir işe sahip olmakla işsizlik (veya işsizlik tehdidi) arasındaki müphem alanda bulunanlar... tıpkı kapitalizmin şafağındaki gibi, 'Iüzumsuz', 'serseri', 'tehlikeli' addedilen, statüsüz bir kitle” (2010, s. 11). Şebnem Oğuz'un "Tekel Direnişinin Işığında Güvencesiz Çalışma / Yaşama" (2011) başıkılı makalesi de, o dönemde gündemde olan direnişi prekarya kavramı bağlamında inceler. Avrupa'da ve Türkiye'de yapılan işçi / işsizlik eylemlerinin farklılıklarına dikkat çeken Oğuz, Avrupa'daki eylemleri genç nüfustaki sınıf bilincinin oluşmasıyla bağdaştırırken, Türkiye'de yaşananları zaten var olan bir sınıf bilincinin kenetlenmesi şeklinde okumuştur (2011, s. 21). Oğuz'un bu farklııklara dikkat çekmesi, dünyanın çeşitli coğrafyalarında işçi haklarının nasıl ele alındığını görmek açısından önemlidir. Tekel direnişi ile birlikte, prekarya kavramı Türkiye özelinde de tartışılmaya başlanmıştır.

Daha sonrasında, Türkiye'de emek ve güvencesizlik üzerine birçok alandan çeşitli çalışmalar yapılmıştır. Bu çerçevede Kürt iş̧̧i emeği, akademideki güvencesizleşme, göçmen işçiler, seks iş̧̧iliği gibi ilk bakışta birbiriyle bağlantılı gözükmeyen alanlardan söz etmek mümkündür. Prekaryanın önerdiği, görünmez emeklerin de görünür kılınmasıdır. Genel olarak bakıldığında, Denizcan Kutlu'nun da belirttiği gibi, “[...] Türkiye'de çalışmanın giderek daha da güvencesizleşmesinden söz etmek yanlış olmayacaktır. Getirilmek istenen düzenlemelerle istihdamın daha güvenceli bir nitelik taşımayacağı anlaşılmaktadıı" (Kutlu, 2012, s. 111). Güvencesizlik, bu noktada sadece iş hayatıyla ilgili değil; sağlık, eğitim, barınma gibi birçok temel iş̧̧i hakkıyla da kesişim içerisindedir.

Türkiye sınırları içerisinden bakıldığında, prekarya tartışmalarını ilk olarak etnik kimlik temelli ayrımcılıkla birleştirmek pek de zor olmayacaktır. İş alanındaki güvencesizlik ve eşitsizlik, etnik kimlik ekseninde ayrımcılığa maruz kalan çalışanlar için daha belirgin olmaktadır. Ferda Koç'un “Iş̧̧ileşme Sürecinin Kürt Segmenti veya Kürt İşçilik Sorunu” (2012) isimli makalesi, etnik kimliklerin güvencesizlikle olan bağını incelemektedir. Koç makalesinde, “proleterleştirme sürecinin, 'dirençsiz', 'dayanıksız', 'yaralanabilir', 'otorite altına alınabilir' toplum kesimlerine odaklandığını" belirterek şunları söyler: "Ezilen bir halk olarak Kürtler, bu özelliklerin birçoğunu birlikte taşımaları nedeniyle, proleterleştirme sürecinin temel bileşenlerinden biridir" (2012, s. 148). Koç'un altını çizdiği sorun, çalışanları ekonomik gelirle 'terbiye' etmenin dezavantajı gruplarda daha kolay gerçekleşebilmesidir. Ayrıca, Polat Alpman'ın Esmer Yakalılar isimli kitabı da, Kürt emeğinin kırılganlığından bahseder. Kürt 
emeğinin sömürülmesine yol açan prekaryalaşmada etnik köken de belirleyici bir rol oynamaktadır (Alpman, 2016, s. 69). Koç ve Alpman'ın ortaklaştığı nokta, işçi kimliği dışında daha farkıı kimlik kategorileriyle, kırılganlığın çok katmanlı bir boyuta gelebileceği fikridir.

Coğrafi sınırlar; savaş, terör, kıtlık ve yoksulluk gibi nedenlerle değiştirildiğinde, yasa-dışı koşullarda çalışmak da prekarya üzerinden tartışmaya açılabilmektedir. Kayıt dışı varoluş; kırılganlığı, güvencesizliği ve yaralanabilirliği açık bir şekilde arttırmaktadır ve bunun prekarya tartışmalarında geniş bir yer bulması gerekmektedir. Nazlı Şenses "Rethinking Migration in the Context of Precarity: The Case of Turkey" (2017) başıklı makalesinde güvencesizlik meselesini göçmenler özelinde tartışmaya açan bir bakış açısı sunmuştur. Hem kırsaldan - kente göçenler, hem de Suriye'den Türkiye'ye yasadışı olarak göçenlerde prekaryalaşma mutlak ölçüde görülmektedir. Şenses'e göre; düşük gelir, niteliksizlik (de-qualification), çocukların eğitime erişememesi ve ayrımcılık göçmenlerin yaşadığı sorunlardan bazılarıdır (2017, s. 109). Şenses ayrıca Türkiye sınırları içerisinde güvencesizliğin yeni bir sorun olmadığının da altını şu sözlerle çizer: "Türkiye'de prekarite yeni bir durum değildir ve düzensiz göçmenler tarafından ilk kez yaşanmamıştır [...] Türkiye'de sadece uluslararası göçmenler değil, aynı zamanda çok sayıda göçmen-olmayan işçiyi de kapsayan çok büyük bir kayıt dışı ekonomi bulunmaktadır" (2017, s. 112 - 14). Kayıt dışı varoluş, elbette ki hali hazırda var olan kırılganlığı derinleştirmekte ve buna yeni katmanlar eklemektedir. Şenses'in alana katkısı, prekaryayı göçmen ve kimliksiz insanların koşulları ile birlikte değerlendirmesidir.

Prekarya, sadece dezavantajlı gruplara değil, görece güvenli ve korunaklı olduğu varsayılan alanlara da nüfuz etmiştir ki bu durum prekarya tanımına dâhil olan faktörlerden biridir. Güvencesizlik ve kırılgan olma durumundan etkilenen başka bir alan olarak eğitim ve akademiden söz etmek mümkündür. Hem elde edilen akademik formasyon ile icra edilen meslek arasında gitgide oluşan uçurumların hem istihdam edilmiş akademisyenlerin çalışma olanaklarının göz önünde bulundurulması gerekmektedir. Esra Çolak, “Akademide Güvensiz Çalışma" (2015) başıklı makalesinde, eğitim alanındaki güvencesizleşme deneyimlerini araştırma görevlileriyle yaptığı derinlemesine görüşmeler üzerinden incelemiştir. Çolak'ın vurguladığı durum, akademik istihdam sürecinde ve sonrasında en temel "güvence ihtiyacının sağlan[maması]", prekaryalaşmanın sadece eğitim seviyesine bağı olmadığını kanıtlar niteliktedir (2015, s. 42). Çolak'ın araştırması göstermektedir ki, akademik eğitim eskiye nazaran daha kırılgan bir durumdadır. Bu nedenle güvencesizlik, sadece eğitimsizlik üzerinden okunamamaktadır. Genel olarak, Türkiye'deki prekarya üzerine yapılan çalışmalarda daha 
öncesinde güvencesi olup bu güvenceyi zaman içerisinde (özelleştirmeyle birlikte) yitirmiş işçilerin, Kürt emekçilerin, göçmenlerin ve akademisyenlerin kırılganlığının altı çizilmiştir.

Prekarya hakkında yapılan en güncel ve kapsamlı çalışmalardan biri ise Alphan Telek'in Artık Hepimiz Prekaryayı (2020) isimli kitabıdır. "[Prekaryayı] hisleri giderek ortaklaşan insanların oluşturduğu bir topluluk olarak" ele alan Telek, maddi gelir üzerinden bir ekonomik sınıf kurmaktansa, ortak zemini daha farklı yerlerde aramaya çalışır (2020, s. 21). Telek'in savunduğu "[...] gündelik yaşamdaki ilişkiler, deneyimler ve hislerin bir sınıfı sınıf yapmaya yeten unsurları içer[diği]" fikri, çalışmada oldukça sık dile getirilmiştir (2020, s. 42). Sınıf tartışmaları konusunda da Telek, Standing'le aynı hatta durur: "Bir sınıfı belirleyen şey üyelerinin aylık gelirleri değil onların üretim ve dağıtım ilişkilerindeki konumları, paylaştıkları ve sınıfsal hisleridir. Bir başka deyişle güvencesizlik, birikimsizlik, belirsizlik beş bin lira kazananla bin yedi yüz lira kazananı aynı sınıfın üyeleri yapmaya yeter" (2020, s. 92). Diğer bir deyişle, ekonomik bir sınıftan daha çok, prekaryadan bahsederken deneyimler ve hisler ön plana çıkarılmıştır. Tüm bu tartışmalara bakıldığında denilebilir ki, prekarya kavramı ulusal sınırlar içerisinde de hala çeşitli alanlarda gündemdedir. Aynı zamanda, kırılganlığın ve güvencesizliğin toplumun neredeyse her kesimiyle ilgili olduğu vurgulanmıştır.

Prekarya, yukarıda da bahsedildiği gibi salt maddi yönden güvencesizlikle açıklanması zor bir kavramdır. Bunun ötesinde; kırılganlığın, belirsizliğin ve güvencesizliğin iç içe geçtiği bir varoluştan bahsetmek mümkündür. Judith Butler ve Isabell Lorey kırılganlık üzerinden daha ontolojik bir tartışma yürütmüşlerdir. Lorey'in de belirttiği gibi, "prekar ve dağılmış olan sadece iş değil, hayatın kendisidir" (2015, s. 9). Kavramın bu açıdan ele alınması, prekaryayı daha varoluşsal ve çok boyutlu bir açıdan ele almamızı da sağlamaktadır. Judith Butler hem Kırılgan Hayat (2005) hem de onu takiben yazdığı Savaş Tertipleri (2015) isimli kitaplarında; kırılganlık, yaralanabilirlik ve yası tutulabilirlik üzerine oldukça kapsamlı tartışmalar yürütür. Butler yaralanmayı olumsuz çağrışımlarıyla düşünmekten ziyade, meselenin daha birleştirici yönüne odaklanır.

Butler yaralanmadan söz ederken, insanın elinde olmayan bir ortaklığa vurgu yapmaktadır: "Yaralanmanın kazandırdığı bir şey, hayatımın bağımlı olduğu ötekilerin, tanımadığım ve belki de hiç tanımayacağım insanların bulunduğu sezgisidir" (2005, s. 10). Butler'ın yaralanma üzerine düşüncelerinden hareketle denilebilir ki, her insan ortak bir yaralanabilirlik zemininden birbirine bağlıdır. Son olarak, hiçbir iktidar kurmaya çalıştığı otoriteyle bu koşulu ortadan kaldıramaz. En nihayetinde, yaralanabilirlik, insan varoluşuyla 
perçinlenmiştir. Tüm bu tartışmaya, özellikle Pandemide Seks İş̧ileri belgeseli incelenirken geri dönülecektir.

Lorey de, Butler ile benzer bir hatta, kırılgan olmayan bir varoluşun imkansızlığından söz eder: "Korunmaya ihtiyaç duysalar da, özellikle de hayatın istikrarsız olduğu sosyal ve politik koşullara kalıcı olarak maruz kaldığı için yaşayan bedenler asla tamamen korunamaz" (2015, s. 20). O zaman, bedenin yaralanabilirliği, hiçbir zaman sınırsız bir korunmaya tabii değildir. Ayrıca Lorey, kırılganlık tanımın kendisi üzerine de düşüncelerini belirtir: "Kırılganlık zemini kurmaz, genel olarak tanımlanamaz ve tek başına var olamaz. Özellikle de her zaman başkalarıyla ilişkili olarak var olduğu ve bu nedenle sürekli olarak sosyal ve politik eylem olanaklarıyla bağlantılı olduğu için tanımsız kalır" (2015, s. 100). Kavramın net sınırlarla tanımlanamazlığı, çeşitli kesimlerin bir araya gelmesine de imkân sağlamaktadır. Kırılganlığın ilişkiselliği, tek bir ortak zeminden ziyade, çoklu bir ortaklık kurmayı hedefler.

Kısaca toparlamak gerekirse, bir sınıf olarak prekarya, kırılganlık, güvencesizlik ve tüm bunların emekle olan ilişkisi üzerine çok çeşitli alanlarda fikirler üretilmeye devam etmektedir. Prekaryaya toplumsal cinsiyet temelli bakıldığında da, "en nihai kırılgan işçilik" olarak seks işçiliğini görmemek oldukça zordur (Sanders ve Hardy, 2013, s. 16). Buna rağmen seks iş̧̧iliği, prekarya üzerine yapılan tartışmalarda dikkate alınmamıştır. Bunun nedenleri ve sonuçlarına Pandemide Seks Iş̧̧ileri belgeseli incelenirken detaylı bir şekilde değinilecektir. Tüm bu kavramsal çerçeve ışığında, Eve Sığmayan Hayatlar ve Pandemide Seks İş̧ileri belgeselleri incelendiğinde, sahip olunan hakların iktidar tarafından daha da kırılganlaştırıldığı söylenebilir. Ayrıca, yasanın dışında tutulmasıyla yaralanabilirliği yüksek olan grupların salgın nedeniyle çok daha kırılgan hale gelmesi de söz konusudur.

\section{Eve Sığmayan Hayatlar: Zemini Çatlayan İşçi Hakları}

Eve Sığmayan Hayatlar, yönetmenliğini Sertaç Yıldız’ın üstlendiği, Covid-19 döneminde herkesin evde olduğu zamanlarda dışarıda çalışmak durumunda kalan iş gruplarından birer kişiyle yapılmış görüşmeleri içeren bir belgeseldir. "Evde kalamayanların hikâyesi" olarak kendini tanımlayan filmde; bir hemşire, bir market çalışanı, bir kargo görevlisi ve bir bankacının salgın dönemini nasıl deneyimlediklerine odaklanılmıştır. Türkiye Insan Hakları Vakfı (TiHV) 11. Insan Hakları Belgesel Film Günleri'nde de gösterilen filme, çevrimiçi olarak YouTube'dan erişilebilmektedir.' 
Belgeselde ilk dikkat çeken nokta, normal şartlar altında bir araya gelmeyecek olan iş kollarının "essential workers" (temel / zorunlu işçiler) kategorisi altında bir arada anılmasıdır. Her ne kadar sosyal güvenceleri, çalışma şartları, gelecek kaygıları ve sendikal hakları gibi birçok noktada ayrılsalar da, belgesel tüm bu iş̧̧ileri aynı anlatıda bir araya getirmiştir. O zaman belgeseldeki iş kollarını tek tek incelemeden önce ilk söyleyebileceğimiz, zamanın ve durumların yarattığı koşullarda, birbirinden farklı kırılganlıkların birbirine bağlanabilmekte olduğudur. Lauren Berlant, Cruel Optimism (2011, s. 201) isimli kitabında, "Prekarite Sineması" olarak tanımladığı filmlerdeki bağı "dayanışmanın yeni potansiyel durumlarını öznelerin benzer tarihsel kimlikler ya da sosyal mekânlarda kurulmasında [...]” aramaz (2011, s. 201). Bunun yerine, tarihsel veya kategorileştirilmiş kimliklerin ortaklığı, baskı rejimlerine karşı kendilerini adapte edebilmelerinde aranabilmektedir. Berlant'ın prekarite sinemasını açıklarken kullandığı "sıradanlık" sıfatına Bardan "insanların yaşamlarındaki mevcut baskılara sürekli uyum sağlamaya çalıştıkları krizle şekillenen bir çıkmaz" açıklamasını getirmiştir (Bardan, 2013, s. 70). Öyleyse, belgeselin dayanışma potansiyeli, çalışanların kendilerini salgın koşullarına nasıl adapte ettiklerinde bulunabilir. Salgın koşulları, farklı iş kollarında çalışan bu emekçileri, toplumun evde kalabilme şansına sahip kesimlerin dışında kalmaları ve işe gitmek zorunda olmaları nedeniyle birbirlerine yakınlaştırmıştır.

Eve Sığmayan Hayatlar'ın yer verdiği perspektiflerden biri bir kargo çalışanına aittir. Belgeseldeki kargo görevlisi "Z", iki yıldır kurumsal bir kargo firmasında görev yapmaktadır. Ancak mobbing sebebiyle işten ayrılmak zorunda bırakılmıştır. Bu iş kolunda, pandemi dönemindeki çalışma şartlarının ağırlığı, riske açıklık ve adaletsizlik dikkat çeker: "Ülkenin mevcut ekonomik koşullarında hayatımı sürdürmem gerekiyor. Ya evde kalarak sağlığımı koruyup açlıktan öleceğim ya da sağlığımı hiçe sayıp para kazanmayı seçeceğim". "Z"nin burada vurguladığı çıkmaz şudur ki, güvende olabilmek ve sağlıklı kalabilmek (yani evde olabilmek) ancak "ayrıcalıklı" bir sınıfa mahsustur: "Hayat Eve Sığar, sadece belirli bir sınıfın uyabileceği bir politikaydı. Salgın boyunca çalıştığımız her an, bu ayrıcalıkı sınıfla aramızdaki uçurumun daha da derinleştiğini hissettik." Bu durum keyfi olarak evde kalanlarla zorunluluktan dışarıda çalışmak durumunda olan "zorunlu işçiler" arasında farkı daha da kuvvetlendirir. Pandemi dönemindeki çalışma şartları son derece farklıdır. "Z"nin de vurguladığı gibi, artan iş yüklerine ek olarak, işçilerin izin hakları da gasp edilmiştir. Mevcut şartlar, hem fiziki hem de psikolojik olarak, çalışanları daha da güvencesizleştirir. Bu yıpratıcı süreklilik, çalışıyor olmaya tekabül eder. Dahası, yöneten ve çalışan arasındaki uçurum bu 
güvencesizliği daha da sağlamlaştırır. "Z" bu adaletsiz dağılımı şöyle dile getirir: "Biz kargo çalışanları her gün o kargolarla aynı ortamda yüzlercesine temas halindeyken genel müdürlük ve bölge müdürlüğü çalışanları home office ve vardiya düzenine geçerek kendi sağlıklarını korumaya giriştiler". Öyleyse burada vurgulanan şudur: Daha kırılgan kılınan, tehlikeye açık bırakılan ve olanaksızlıklar içinde kalan her zaman daha riskli koşullar altında çalışmaya zorlanandır. Ancak "Z"nin de dediği gibi aslında uygulanması gereken ise şudur: "Ekonomik yaşam bir şekilde sürekli devam etmek zorunda olduğu için birileri sürekli çalışmak zorunda. Ancak salgını durdurmak için bir karantina uygulanacaksa halkın tamamına uygulanmalıydı."

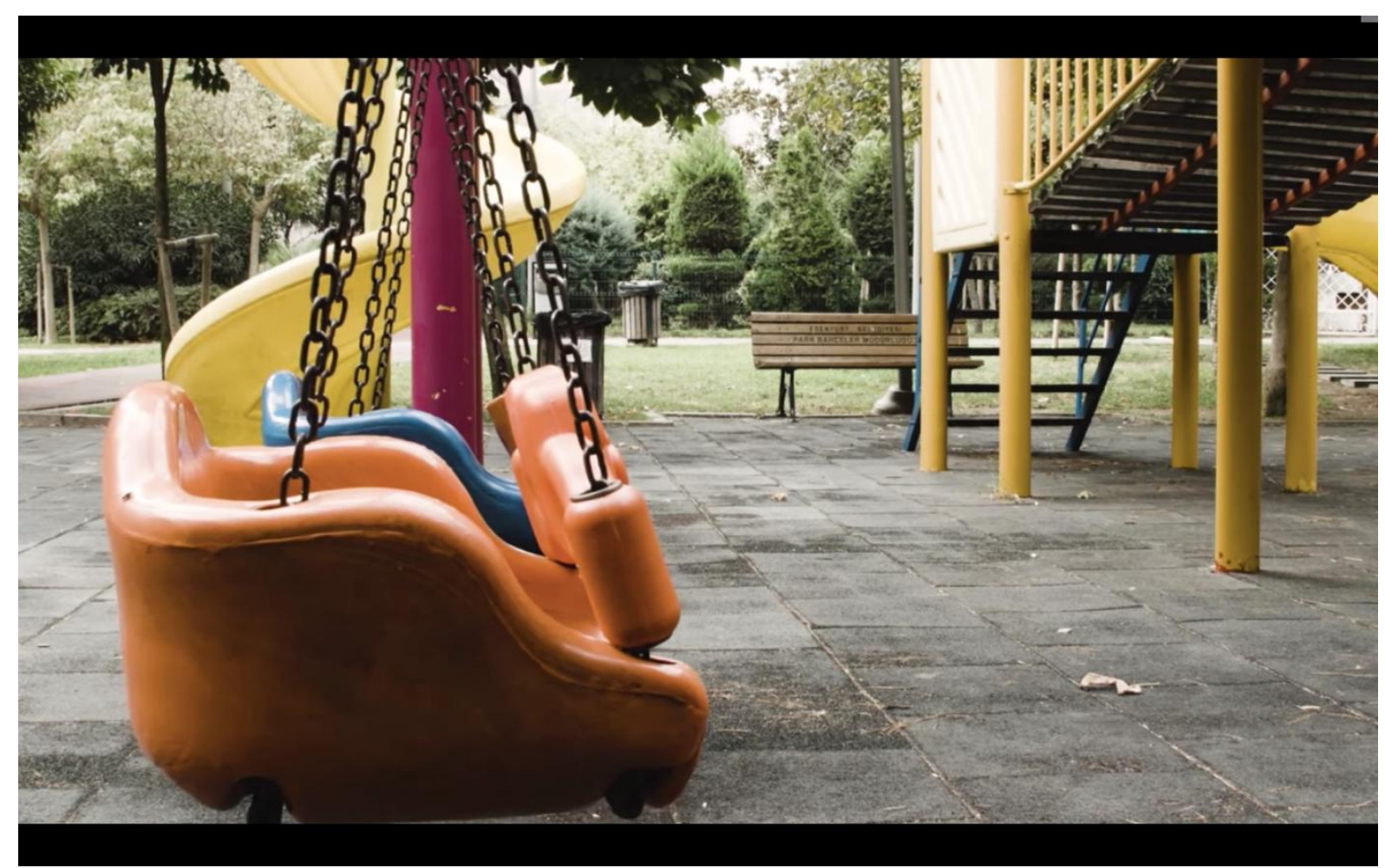

(Eve Sığmayan Hayatlar, Sertaç Yıldız, 2020)

Benzer güvencesizliklerin vurgulandığı belgeselde odaklanılan diğer iş kolu hemşireliktir. Bu örnekte gördüğümüz ise sosyal güvencesi olan bir mesleğin dahi salgın döneminde kırılganlaşabildiğidir. 27 yıldır hemşirelik görevi yapan " $M$ ”, beş yıldır Devlet Hastanesi'nde, üç yıldır ise yoğun bakım servisinde hemşire olarak çalışmaktadır. " $M$ "'in de bahsettiği gibi gerekli koruyucu ekipmanın geç ulaşması bu güvencesizliği sağlayan baş faktörlerden biridir. Bunu kendisi şöyle dile getirir: "Kendi önlemimizi kendimiz almak zorunda kalıyorduk." Kendisinin de vurguladığı gibi, bu zaten son derece risk teşkil eden halin temelinde yatan güvencesizlik, üstlerinden gelen yüzeysel bir "virüse yakalanmayın" tavsiyesi ile daha da belirginleşir. 
Yönetenlerin tecrübe ettiği güvencesizlik daha 'güvenli' kılınırken, çalışanların tecrübe ettiği 'güvencesizlik' ortadan kaldırılmaya çalışılmaz, onlar tehlikeye ve riske her zaman daha açık bırakılmıştır. Bir kez daha fiziksel ve psikolojik yıpranmanın vurgulandığı bu iş kolunda, güvencesizliğin bilhassa pandemi döneminde sistematik bir şekilde devam ettirilmesine tanıklık ederiz.

Belgeselin ele aldığı başka bir iş kolu ise bankacılıktır. 10 yıldır kurumsal bir bankanın merkezi bir şubesinde çalışan " $Y$ ", bankanın hem gişe hem de satış bölümlerinde görevlidir. $Y$ işyerine giderek çalışmak gitmek zorunda kalırken, bankanın üst düzey yöneticileri evden çalışma imkânına sahiptir. "Y"nin kendisini yöneticisinden ayırdığı sözler, kırılganlığın da eşit işlemediğini göstermektedir: "Farklıydık ve hayat bu farklar üzerine kuruluydu. Evde kalanlar ve kalamayanlar." Aynı zamanda, yönetenler ve çalışanlar arasındaki eşitsizliğin salgın sürecinde nasıl kristalize olduğunu da şu sözlerle açıklar: "Bu gerçeği, ne kadar değersiz olduğumuzu, bu denli net olarak bir kez daha görmek ağırdı." Y, bankaların çalışanlarına şikâyet hakkı verdiğini belirtir, ancak herhangi bir şikâyette o elemanın sistematik olarak mobbinge maruz bırakıldığının da altını çizer. $Y$, işten istifa etme ve hayatını idame ettirme ikilemi arasında kalmıştır. Her an yerine başka bir elemanın alınabileceği gerçeği, çalışanlar için eleştiri ve şikâyet mekanizmalarının önünü kapatır. Belgeselde vurgulanan bu nokta, Telek'in prekarya ve işsizlikle ilgili fikirlerine paraleldir: "İşinizden edilme korkusu yaşarsanız, bu sizde derin bir güvencesizlik hissi oluşturur. Hisler çok kuvvetlidir, tıpkı hayvan sürülerine yön verdiği gibi, insan gruplarına da yön verir. İtaat etmeyi, susmayı, içinize atmayı, daha fazlasını istememeyi öğrenirsiniz" (2020, s. 80). Performatif süreklilik, evde kalamama ve yöneten ile çalışan arasındaki dengesizlik, belgesel ile prekarya üzerine yapılan tartışmalar arasında köprü kurma imkânı vermektedir. 


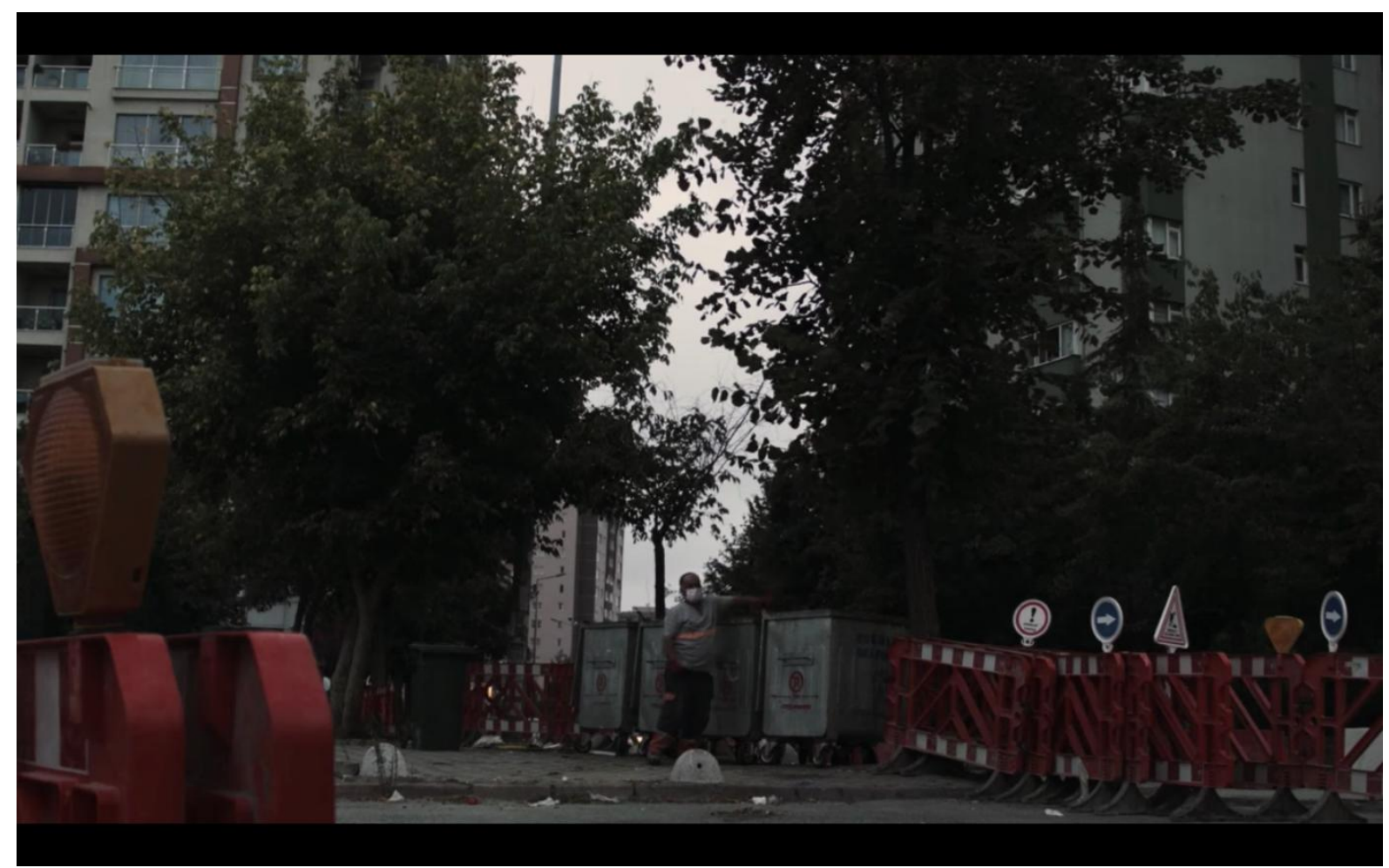

(Eve Sığmayan Hayatlar, Sertaç Yıldız, 2020)

Son olarak belgeselin odaklandığı iş kolu market çalışanlarıdır. Altı yıldır, büyük ve kurumsal bir market zincirinde personel olarak çalışan "A", kalabalık bir şubede üç kişi çalıştıklarının altını çizer. Bu zorlu koşullara "herkesin işe çok ihtiyacı olduğu için katlan[dığını]" söyleyen $A$, kolayca yerine birinin geçebileceğinden, esnek çalışma saatlerinden ve iş yükünün ağırlığından bahseder. Özellikle pandemi sürecinde marketlerin yoğun oluşundan ve çalışma saatlerinin sürekli değiştirilmesinden şikâyetçidir: "iş̧ yoğunlu içinde salgınla ilgili kararları da takip edemiyorduk. Bir anda marketler 23.00’a kadar açık olacak diye açıklama yapıyorlar. E müşteri bilmediği için gelmiyor ama biz bekliyorduk. Bu tip belirsizlikler de çok can sıkıcıydı." Salgın kaynaklı stres, iş yoğunluğu ve belirsizlik, prekaryanın deneyimlediği hem maddi hem de manevi güçlüklere işaret etmektedir. Prekaryanın esnek, kırılgan ve güvencesiz çalışma koşullarına ilişkin olarak Telek şunları söyler: "[...] prekaryanın zamanı [proleteryanınki gibi] değil. Ondan her an iş yapması bekleniyor. Belli bir mesai saati yok. Teknolojinin de yardımıyla ondan her an iş için hazır olması bekleniyor [...] Böylece prekaryanın zamanına ulaşıyoruz. Güvencesiz sınıfın güvencesiz ve kırılgan zamanı" (2020, s. 86). Buna göre, her an işe hazır olma durumu, prekaryayı proleteryadan ayıran özelliklerden biridir. Belgeseldeki market çalışanın deneyimi, Telek'in "güvencesiz sınıfın güvencesiz ve kırılgan zamanı" ifadesini somutlar niteliktedir. Salgın, zaten hâlihazırda var olan bu kırılganlığı derinleştirmiştir. Kırılgan 
zamanın, sadece market çalışanları için değil, evden çalışan diğer iş kolları için de geçerli olduğunu söylemek yanlış olmayacaktır. Özünde, market çalışanının kırılganlığı seyirciye aktarılırken, özellikle güvencesizlik ve esnekliğin getirdiği bir manevi yaralanmadan bahsetmek mümkündür.

Filmin görsel ve işitsel tercihleri konusunda da güvencesizliğin belirleyici olduğundan söyleyebiliriz. Belgeselde çalışanların yüzlerinin hiçbir sahnede görünmemesi ve kendilerini üst-ses ile anlatmaları (ki bu üst-ses aslında çalışanların gerçek sesleri değil, anlatııların onların ifadelerini seslendirmeleri) da dikkat çekicidir. Çalışanların her ne kadar koşullarından şikâyetçi olsalar da bir noktada o işe bağımlı oldukları için birer özne olarak belgeselde doğrudan yer alamamışlardır. Diğer bir deyişle, her ne kadar prekar olsalar da, hayatta kalmaya devam etmek için o güvencesizlik içerisinde çalışmak zorunda olma hissi, çalışılan kuruma / şirkete getirilecek en ufak bir eleştiride işini kaybetme korkusu, filmin görsel ve işitsel öğelerine de sinmiştir. Bu görün(e)meme ve duyul(a)mama hali, çalışanların günlük hayatlarındaki ikame edilebilirliklerinin, "yok"luklarının, gözden çıkarılabilirliklerinin altını çizer gibidir.

Hayatları eve sığmayan çalışanların kendi imge ve sesleriyle anlatıya dâhil olamamasının yanında, açılıştaki kalabalık cadde görüntüsüne tezat biçimde sokağa çıkma yasakları esnasında insansızlaşmış şehir manzaraları da ekrana yansır. Yavaşlatılan, hızlandırılan, bulanıklaştırılan, iç içe geçen görüntüler, eğik kamera açıları, sıçramalı kurgu, çerçevenin bölünmesi, renklerde oynama gibi deneysel tercihlerle yaratılan tekinsizlik hissi aracılığıyla da kırılganlığın ve güvencesizliğin altının çizildiği düşünülebilir. Film boyunca bu özneler ile yapılan röportajlardan alınan ifadeler anlatıcı sesi dolayımıyla aktarılırken Covid-19 Pandemisinin Türkiye'deki seyrine ilişkin bilgiler ve istatistikî veriler de görüntüler üzerinde yazı ile verilir. Bu didaktik unsur belgeselle seyirci arasına bir duvar örmektedir. Denilebilir ki, Yıldız’ın belgeselciliği bilinçli bir biçimce mesafeli ve soğuktur. 


\section{Pandemide Seks Iş̧̧ileri: Sistematik Bir Şekilde Göz Ardı Edilen Iş̧̧i Hakları}

Prekarya tartışmalarında en çok göz ardı edilen iş kollarından biri seks işçiliğidir. Bunun en temel nedenlerinden biri, bu türden bir emeğin hâlâ emek olarak sayılmamasıdır. Nicola Smith "Queer and/in Sexual Economies" (2015) başlıklı makalesinde, seks işçiliğini çerçeveleyen söylemden şöyle söz eder:

Ticari seks şiddet, baskı, sömürü, sapkınlık, sapıklık, hastalık, zevk vb. olarak inşa edilmiştir, ancak nadiren 'iş' olarak kabul edilmiştir ve bu şekilde hala daha az meşrulaştırılmaktadır. Ilginç bir şekilde, bu kurumsal ve kültürel meşruiyet eksikliğinin kendisi, ticari seksi kırılgan bir emek biçimi olarak üretebilir (Smith, 2015, s. 19).

Aslında, seks işçiliğini kriminalize eden, tam da bu emek biçiminin görmezden gelinmesidir. Eğer bu emek görünür kılınırsa, hem sosyal hem de yasal haklar açısından prekarya tartışmalarının içerisinde seks iş̧̧iliğine yer vermek mümkün olacaktır. Bu nedenle, yazının bu kısmında seks işçiliğinin prekarya ile kesişebilecek noktaları ele alınmaktadır.

Öncelikle, feminizm içerisinde kendisine alan açan trans-feminizm, seks işçiliği üzerine de sözler üretmektedir. "Transfeminist Manifesto" (2013) bu tartışmanın en temel metinlerinden biridir. Bu yazısında Emi Koyama, feminist ve trans / kuir / na-ikili varoluşların ortaklaşabileceği bir alan açar. Özellikle feminizmin biyolojik özcülüğü karşısında duran bu manifestoda, seks iş̧̧iliği yapan transların maruz bırakıldığı şiddete karşı şu sözler dile getirilir: "Medya ve otoriteler, seks işçilerinin olduğu gibi, trans kadınların öldürülmesini de, nadiren ciddiyetle veya mağdurların tarafından ele alıyor - özellikle de mağdur seks işçiliği yapan bir trans kadınsa" (Koyama, 2013, s. 370). Bundan yaklaşık yirmi yıl önce kaleme alınan manifestoda Koyama, özellikle kesişimsel bir hat çerçevesinde, iktidarın, heteronormativitenin, patriarkanın ve cis-temin ${ }^{i i}$ beden üzerine ürettiği söylemlerde, kadın, trans, kuir ve na-ikili bedenlerdeki dışlayıcı ve çeperde tutucu politikalarını ortaklaştırmıştır. Aynı tartışmayı salt trans kimliği ve seks işçiliği çerçevesinde ele alan Rev ve Geist'in "Staging the Trans Sex Worker" (2017) başlıklı makalesi de, Koyama ile paralel fikirlerden yola çıkarak trans seks işçilerinin ekonomik sorunlarını dile getirir: "Maruz bırakıldıkları ayrımcılık ve içinde bulundukları ekonomik kırılganlıkları düşünüldüğünde, trans kimlik--en azından emek ve materyal açılardan-- aşırı belirlenime (overdetermined) açık bir haldedir" (2017, s. 117). 
Ayrımcılık ve ekonomik güçlük ile birlikte ele alındığında, buradaki emeğin görünmez kılınması, sistematik olarak bir varoluşun göz ardı edilmesini de beraberinde getirmektedir.

Türkiye'de seks işçiliği üzerine yapılan çalışmalar kısıtlı bir alanı kaplasa da, bu metinlerden birkaçı dikkat çekmektedir. Öncelikle Aslı Zengin'in Iktidarın Mahremiyeti (2011) isimli kitabı, İstanbul'da yaşayan ve çalışan kadın, eşcinsel, trans seks işçileri üzerine etnografik bir incelemedir. Bu çalışmasında Zengin, seks işçiliğini devlet kontrolü ve iktidar üzerinden ele alır. Özellikle kayıtdışı olma, can güvenliğinin olmayışı ile hukuki araçlardan yoksunluk arasındaki bağlantıyı Zengin şu şekilde açıklar:

Kayıtdışı seks iş̧̧iliğine dair düzenlemeler ve polisten duyulan korku, hayat kadınlarının güvenliğine ilişkin taleplerini ciddi biçimde şekillendiriyor. Şimdiye kadar sayısız tecavüz ve öldüresiye dayak yeme vakalarının mağduru olmalarına rağmen, sıradan bir vatandaşın sahip olduğu hak arama ve dava etme yollarına korkusuzca başvuramıyorlar (2011, s. 130).

Buna göre, eğer emek biçimleri arasında bir eşitlenmeden söz edilecekse, en temelde ele alınması gereken durum yaşam hakkı olarak gözükmektedir. Çünkü yasanın dışında kalındığında, iş güvencesinin ötesinde, hiçbir temel haktan söz etmek de mümkün olmamaktadır. Aynı zamanda, Ezgi Güler'in de belirttiği gibi “[...] cinsel kimliklerine yapılan damgalama ve düşmanlık, kriminalizasyon ve sokak-temelli seks işçiliği, cezai kurumsal pratikler, ve neoliberal kentsel yeniden yapılandırma, translara yapılan ötekileştirmeyi daha da şiddetlendirmiştir" (Güler, 2020). Ancak, seks iş̧̧iliğini çevreleyen söylemler sadece olumsuz çağrışımlarla yüklü değildir. Ceylan Engin'in (2018) vurguladığı gibi, bu endüstrinin üzerine yapılan tartışmalar, tek boyutlu olarak ele alınamaz: "Seks endüstrisinde hem güçlendirici hem de baskıcı durumlar meydana gelebilir. Baskı ve güçlendirme paradigmaları gibi tek boyutlu ve yekpare paradigmalar, özellikle Türk toplumunda seks endüstrisinin nasıl işlediğinin inceliklerini tam olarak açıklayacak karmaşıklıktan yoksundur" (2018, s. 198). Tüm bu çalışmalar gösterir ki, cinsel yönelim ve cinsiyet kimliği üzerinden marjinalleştirilenlerin de kırılganlık ve güvencesizleşme tartışmalarına eklenmeleri zorunlu hale gelmiştir.

Tüm bu tartışmalar ışığında bakıldığında, Ayşe Adanalı ve Volkan Işıl’ın Kırmızı Şemsiye Derneği için hazırladıkları Pandemide Seks İş̧ileri belgeseli, özellikle Covid-19 salgını sürecinde seks iş̧̧ilerinin kırılganlıklarını ekrana taşımaktadır.iii Seks iş̧̧iliğinin hala günümüzde meslek olarak tanınmaması, kriminalize edilmesi ve ötekileştirilmesi, değer yargılarına dayalı ayrımcılık nedeniyle, kırılganlığın meslekle iç içe geçtiğini söylemek yanlış olmaz. Filmin bize 
sunmuş olduğu perspektif, yukarıda tartışılan Eve Sığmayan Hayatlar filmiyle de birleştirildiğinde denilebilir ki, kırılganlık her ne kadar herkesi eşit etkilemese de, çalışma kollarını, iş̧̧i haklarını ve güvencelerini tekrar gözden geçirmek için iyi bir fırsat olarak da değerlendirilebilir.

Judith Butler Kırılgan Hayat'ın önsözünde kırılganlığın ve yaralanmanın sahip olduğu potansiyele dair şunları söyler:

Yaralanmanın kazandırdığı bir şey, hayatımın bağımlı olduğu ötekilerin, tanımadığım ve belki de hiç tanımayacağım insanların bulunduğu sezgisidir. Anonim ötekilere olan bu temel bağlıık irademle ortadan kaldırabileceğim bir koşul değildir. Hiçbir güvenlik önlemi bu bağımlılığı önleyemez; egemenlik iddiasıyla uygulanan hiçbir şiddet eylemi dünyayı bu gerçekten arındıramaz (Butler, 2005, s. 10).

Bu kazanım, Butler’ın da ifade ettiği gibi, "kaçınılmaz karşılıklı bağımlılığımız[ın]" farkına varmamızdan başka hiçbir şey değildir (2005, s. 10). Bir önceki belgeselin izleyiciyle paylaştığı sistematik güvencesizleştirme ve kırılganlıkların, bu belgeseldeki trans seks işçilerinin deneyimleri ile örtüştüğü söylenebilir. "Tanımak" bu durumda belirleyici değildir ve aynı zamanda bağımlılığı geçersiz kılabilecek bir önlem de yoktur. Bu bölümdeki yaklaşımımız, filmlerdeki "kaçınılmaz bağımlılıklarımıza" işaret ederek ortaklıkları keşfetmektir. Trans seks işçisi Mısra'nın da belgeselde vurguladığı gibi, hayat bir şekilde evde kalamayan işçiler için devam etmek zorundadır. Ancak ne pahasına? Yazının bu bölümünde, prekarite ve kırılganlık tartışmalarının filmde nasıl görüldüğü tartışılacaktır. Telek, Artık Hepimiz Prekaryayız'da şöyle yazar: "[...] prekarya uçurumun kenarında olanların, güvencesiz ve belirsiz bir varoluş ve yaşam tarzına sahip insanların oluşturduğu bir sosyal sınıftır denilebilir" (2020, s. 23). Butler'ın kırılganlık ve yaralanma aracılığıyla ötekilerle kurulan bağılığı vurgulaması ve Telek'in prekarya tartışması, Pandemide Seks Iş̧̧̧ileri belgeseline bakmak için uygun bir başlangıç noktası olabilir. 


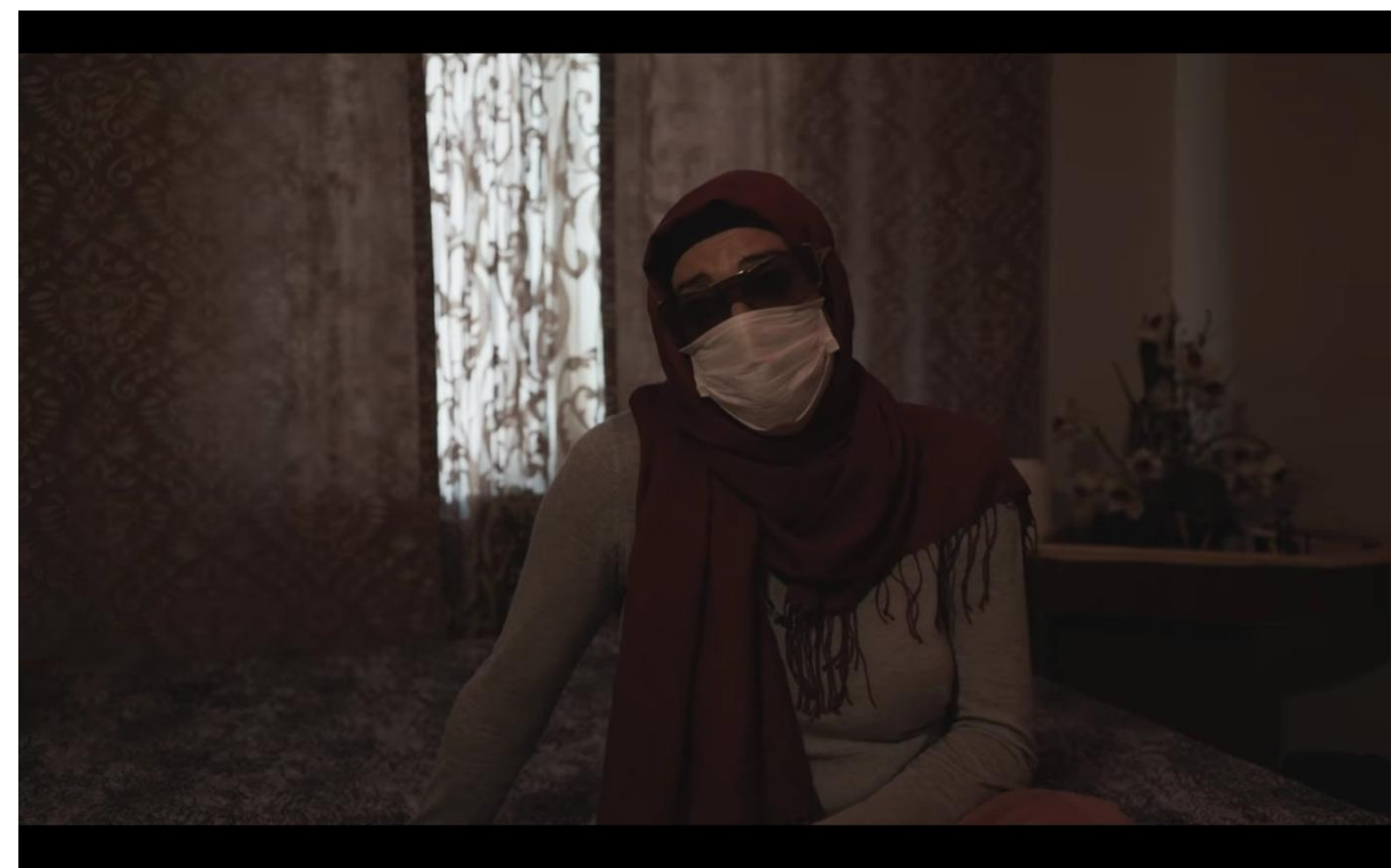

(Pandemide Seks İşçileri, Ayşe Adanalı ve Volkan Işıl, 2020)

Elbette, Butler'ın Kırılgan Hayat ve devam niteliğindeki Savaş Tertipleri'nde vurguladığı şey, kırılganlık ve güvencesizliğin nasıl bir gerçeklik olarak yaratıldığı ve sürdürüldüğüdür. Bu noktada Butler'ın yaklaşımını biraz daha açmamı gerekiyor. Butler'a göre bu iki kavram birbiriyle örtüştüğü gibi, ikisi de siyasi olarak tayin edilirler: "Güvencesizlik, belirli toplulukların toplumsal ve ekonomik destek şebekelerinin eksikliğinden mağdur olduğu ve yaralanmaya, şiddete ve ölüme ayrımcı biçimde maruz kaldığı siyaset temelli bir duruma işaret eder [...] Bir başka deyişle, koruma için devlete başvururlar ama o devlet tam da korunma intiyacı duydukları şeydir" (2015, s. 31). Bu demek oluyor ki çeşitli siyasi şartlar şiddeti üretecek, bu şiddeti sürdürecek ve onu normalleştirecektir. Güvencesizlik, bu şiddet ile el ele hareket edecek ve bu olağanlaştırılmış bir yaralanabilirlik durumuna işaret edecektir: “[...] yaralanabilirlik belli toplumsal ve siyasi koşullar altında, özellikle de şiddetin bir yaşam biçimi olduğu ve güvenli özsavunma yollarının kısıtlı olduğu koşullarda yoğunlaşır" (Butler, 2005, s. 44). Butler, aynı zamanda kimlerin yasının tutulabileceği, kimlerin yasının tutulamayacağını sorgular. Yası tutulabilirlik, bir paylaştırmaya işaret eder. Butler bunu "ayrımcı yas tahsisi" olarak adlandırır (2005, s. 12). Bu tahsis, "kimin normatif olarak insan olduğuna, yaşanabilir bir yaşam ve yası tutulabilir bir ölüm sayılanın ne olduğuna dair belli dışlayıcı kavrayışlar üretmekte ve sürdürmektedir" (Butler, 2005, s. 12). Savaş Tertipleri'nde, Butler bir kez daha 
güvencesizlikle ilgili şu önemli noktaya parmak basar: "[g]üvencesiz hayatın [...] ayrımcı dağılımı hem maddi hem de algı düzeyinde bir meseledir çünkü yası tutulması imkân dâhilinde, yani değerli 'sayılmayan' hayatlar açlık, işsizlik, hukuki haklardan mahrum bırakılma ve ayrımcılıkla şiddet ve ölüme maruz bırakılma yüklerini taşımak zorunda bırakılıı" (2015, s. 31). Öyleyse burada altı çizilen şudur: Güvencesiz bir hayat pek çok yönden yaralanmıştır ve güvencesizlik ölümden sonrasına bile nüfuz etmiştir. Hayatları 'yası tutulabilir' ya da 'tutulamaz' olarak ayrıştırmak tam da bu soruna işaret eder. Bunun somut izdüşümlerini, çeşitli kollardan şiddete maruz bırakılan hayatları ele alırken görebiliriz. Butler’a göre "imha edilebilir" ve "yası tutulamaz" topluluklar, süregelen bir öncelenime tabi olmuşlardır. Yani zaten imha edilebilir ve yası tutulamaz olarak tahayyül edilmişlerdir (Butler, 2015, s. 36). Somut şiddet ve ayrımcı pratikler ise bunu meşrulaştırmak ve/veya haklı çıkarmak için ek birer araca dönüşürler. Butler'ın da üzerinde durduğu gibi, çeşitli olağanüstü haller ve kriz anları ise, bu iktidar pratiklerini uygulamak için biçilmiş kaftandır:

Bu topluluklar "kaybedilebilir" ya da cezalandırılabilir çünkü halihazırda kaybedilmiş ya da cezalandırılmış topluluklar şeklinde tertip edilmişlerdir; gayrimeşru devlet şiddeti, kıtlık ya da salgın hastalıktan korunma ihtiyacı içindeki yaşayan topluluklar olarak görülmez, bilinmez haliyle insan hayatına bir tehdit teşkil eden bir rol üstlenirler. Bunun sonucunda, bu hayatlar kaybedildiğinde yası tutulabilir olmaz çünkü ölümlerini rasyonelleştiren çarpık mantık uyarınca, bu türden toplulukların kaybı "yaşayanların" hayatını korumak için gereklidir (Butler, 2015, s. 36).

Pandemide Seks İş̧ileri belgeselindeki trans seks iş̧̧ilerinin deneyimleri işte tam böyle bir sistematik güvencesizlik çıkmazı içine hapsedilmiş haldedir. Bir kriz anında gözden çıkarılabilir addedilen trans seks işçileri, aslında bu gözden çıkarılabilirlik durumuna pandemi öncesinde de yabancı değillerdir. Covid-19 Pandemisi hâlihazırdaki ayrımcı sistematik yapıyı daha da belirginleştirir. Belgesel, bu kriz anında etkisi daha da art(tırı)mış hayati güvencesizliklerin aciliyetine vakıf olmamızı sağlar. Mısra bu durumu kısa bir soruyla özetler: "Kiramı, borçlarımı kim ödeyecek?" Nora'da benzer bir şekilde bu belirsiz çıkmaza dikkat çeker:

Nasıl yaşayacaksın? Hani hiçbir şekilde yaşayamazsın. Giderlerin var; kiran var; elektriğin var; suyun var; kendine bakmak zorundasın, yemek yemek zorundasın, yaşamak zorundasın. Belki sabit bir gelirin olsa ona göre yaşarsın. Ama bir gün 
kazanırsın, iki gün hiç müşteri gelmez paran olmaz. Bu yüzden hesaplayarak da bir şey yapamıyorsun. Yarının ne olacağını da bilmiyoruz.

Adrian işe şu mecburiyeti vurgular: "Korona gelse de benim için ne yapabilirim ki. Yine devam edeceğim. Korona olsam da devam ederim. Yapacak bir şeyim yok çünkü mecburum. Su alamam. Korona olsam da devam edecek bu". Bu çıkmazı daha da sorunlu hale getiren ise kriz anının, ondan önce gelen ve çoktandır geçerliliğini koruyan güvencesizleştirme pratikleriyle bir araya gelmesidir. Mısra, bu durumu şöyle özetler: "hani hastalansan dadışlanacaksın." Benzer bir şekilde Adrian ise "[k]orona kapsa da kaybedecek hiçbir şeyi[nin] olmadığını" söyleyerek bu göz ardı etme teamüllerinin kriz anından önce de var olduğuna dikkat çeker. Nora, vahşetin koronadan daha ölümcül olduğunu söyleyerek "normal" şartlar altında sürdürülmesine izin verilen felaketlere, yani nefret cinayetlerine ve transfobiye bir kez daha vurgu yapar. Rojin ise bu kökleşmiş ve kriz anında daha da derine kök salabilmesine izin verilmiş sistematik şiddetten şöyle söz eder:

Aslında bizlere yani trans bireyler için korona aman aman bir şey olmadı... Zaten biz sağlıklı bir hayat yürütmüyoruz ki. Normal yaşam şartları olan insanları belki çok korkutmuştur. Zaten biz her an ölümle burun burunayız. Hayattaki en değerli şeylerimizden vazgeçmiş--kaybetmişiz. Biz bu kadar güçlüyken koronadan korkmayız ki... Zaten her türlü riskle her gün iç içesin.

Bunun beraberinde ortaya çıkan (ya da aslında beklenen ve/veya zorunda bırakılan) sonuç ise Butler'ında bahsettiği korunulması gereken şeye başvurmaktır. Elbette bu bir imkânsızlığa işaret eder. Rojin'in buna verdiği örnek şöyledir: “Devletin herhangi vermiş olduğu bir yardım almadım... alamadık. Bulundukları bölgenin sosyal yardımlaşma fonlarına, kredi için şu bu dönüş olmadı. Belirginsen olamıyor mu bilemiyorum... Hani belki biz gidemiyorsak bile, devlet varsa, yerel yönetim varsa o arayıp bizi bulabilirdi de. Yanlış mı?" Benzer bir şekilde Adrian ise hayatını riske atmak zorunda bırakılışını şöyle ifade eder: "Bana sağlayabileceği bir şey olabileceğini düşünmüyorum. İş imkânı verse, ben yine yargılanacağım. Yine homofobik insanlar tarafından, belki sözlü taciz, belki darp. Ama bir para olasılı̆̆ belki sağlanabilirdi diye düşünüyorum. Belki belli bir miktar para olsaydı ben hayatımı bu süreçte ortaya atmazdım." 


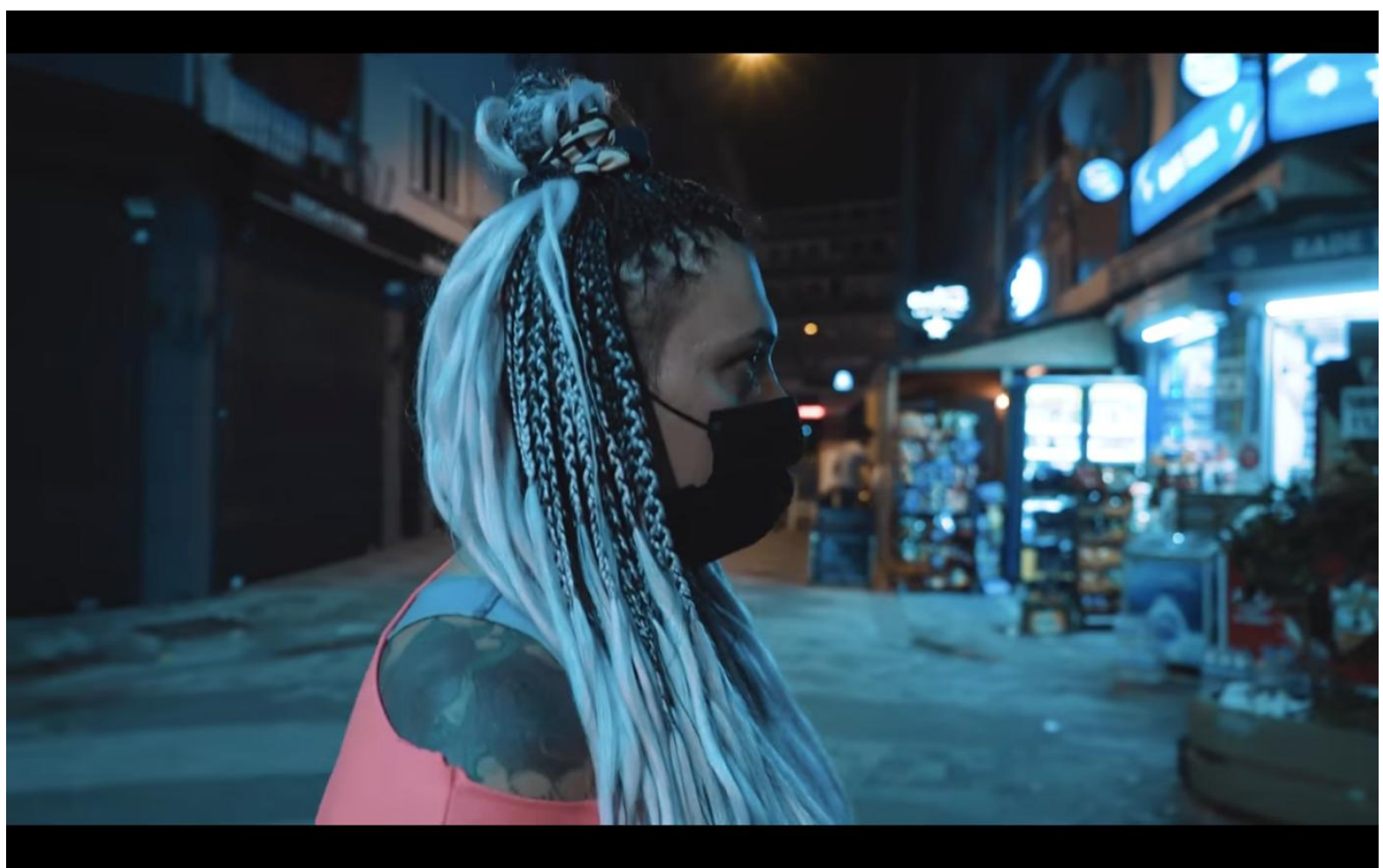

(Pandemide Seks İşçileri, Ayşe Adanalı ve Volkan Işıl, 2020)

Bu sistematik güvencesizliklerin bize gösterdiği, transların ve bu yazı özelinde trans seks işçilerinin, yeterince insan sayılmaması, yaslarının tutulamayacak olması gerektiğini öngören ve onları harcamayı bir gereklilik olarak görmekle kalmayıp, aynı zamanda bunu görünmez kılacak bir krizle ilgilidir. Butler'ın düşünceleri, buradaki tartışmalarla da paralel okunabilmektedir: "Eğer şiddet gerçekdışı olanlara uygulanıyorsa, bu yaşamları yaralamayı ve yadsımayı başaramıyor demektir, çünkü bu yaşamlar zaten yadsınmışlardır [...] [z]aten pek de yaşamamakta olanlara, yani ölüm ve yaşam arasında askıya alınmış olarak yaşayanlara gösterilen şiddet, iz olmayan bir iz bırakır" (2005, s. 48; 51). Bu doğrultuda her türlü şiddet, güvencesizleştirme pratikleri ve cinayet henüz ortaya çıkmadan yok sayılmış ve dolayısıyla meşrulaştırılmıştır: "bir insan hiç olmamış, bir hayat hiç olmamış, dolayısıyla bir cinayet hiç gerçekleşmemiştir" (Butler, 2005, s. 149). Butler'ın bu sözünü, belgeselde Nora'nın dile getirdiği sorunlardan biriyle bağdaştırmak mümkündür: "Yoksun onlar için. Yoksun ve yok olmayan bir şey için de yapılan bir uygulama yok. En azından arkamızda duran bir sistemi görmek isterdim. Ama maalesef yok sayan bir sistem. Ve görmezden geliniyoruz". Bu güvencesizlik, meslekle o kadar iç içe geçmiştir ki birbirinden ayrı anılmamaktadır: "Seks işçiliğinin güvencesizliği veya riski genellikle uygulamanın kendisinin doğal bir özelliği olarak anlaşılmaktadır, ancak alternatif olarak seks işçiliğini çevreleyen risk söylemlerinin maddi bir 
etkisi olarak görülebilir" (Smith, 2015, s. 19). Öyleyse, bu duruma, sistematik bir ötekileştirme ve yok saymaya dayalı politik bir güvencesizleştirme süreci denebilir.

Tüm bu tartışmalar, Berlant'ın, daha sonrasında onun fikirlerinden esinlenen Bardan'ın "Prekarite Sineması" tartışmalarıyla birlikte ele alınabilmektedir. Berlant, bu sinemadaki zamanı "bir geçiş bölgesi" (a transitional zone) olarak imler (2011, s. 201). Bu alanda, "iyi bir hayata sahip olmanın nesilden nesile aktarılan fantezileri artık işe yaramamaktadır" (Bardan, 2013, s. 72). Başka bir deyişle, geçmişteki 'iyi bir hayata' sahip olmanın anlamı, arzuları ve olanaklarını prekarya sinemasında görmek güçtür. Ayrıca, yine Berlant'a göre, prekarya sineması "kolektif tekilliklerin yalnızlığın” kaydeder (2011, s. 201). Tüm bu tanımlamalarla filme tekrar bakıldığında, Pandemide Seks İşcileri'nin prekarya sineması içerisinde konumlandırılması mümkündür. Gereken önemin verilmemesinin yanı sıra kriminalize edilen ve ısrarla merkezin dışında tutulan bir iş kolunun, 'iyi bir hayat' sürme arzusu olarak okunamayışı salgın sürecinde gerçekleşmemiştir. Güvencesizlik, çok daha derin bir boyut kazanmıştır. Ancak, sanatın öznelere bizzat alan açarak bu "kolektif tekilliklerin yalnızlığını" (Berlant, 2011, s. 201) izleyiciye sunması, birkaç açıdan önemlidir. Öncelikle, çok katmanlı olarak dışlanmaya maruz bırakılan bir iş kolu çalışanlarına görsel bir tartışma alanı açılmıştır. Seks işçileri, kendi sesleri, var oluşları ve gerçeklikleriyle kamera karşısına geçerek yaşadıklarını belgesel aracılığıyla dile getirmişlerdir. Son olarak, tarihin görünmez kıldığı ve kayda değer bulmadığı yaşamlara yine belgesel diliyle bir arşiv niteliği kazandırılmıştır. Tüm bunlar bir arada düşünüldüğünde, Pandemide Seks Iş̧̧̧ileri varoluşsal güvencesizliklerin tartışıması ve dile getirilmesi bakımından bir eşitlenme imkânı sağlamaktadır.

\section{Sonuç Yerine: Zemini Yeniden Düşünmek}

Bu yazıda, Covid-19 döneminde üretilen belgeselleri özellikle prekarya, kırılganlık ve güvencesiz varoluş üzerinden okumayı denedik. Prekarya, günümüz kapitalist toplumlarında, sınıf bilincini sadece ekonomik yönüyle ele almayan, birçok görünür veya görünmez emek biçimini birbiriyle diyalog halinde tutmaya çalışan bir terimdir. Göçmen, kayıt dışı çalışan, sığınmacı, geçici iş̧̧i, işsizlikle terbiye edilen, kariyerleri baltalanan, etnik kimliğinden dolayı işyerinde ayrımcılığa uğrayan, iş aramaktan umudunu kesen herkesi kapsamaktadır prekarya. 
Tüm bu tartışmaları "normal” $i$ sorgulayan iki belgesel üzerinden incelediğimizde önemli birkaç noktanın altı çizilebilir: Bunlardan ilki, her ne kadar bu belgeseller birbirinden farklı iş kollarını ele alsalar da, kırılganlıklar ve güvencesizliklerin söz konusu emek biçimleri arasında bir bağ kurabilecek güçte oluşudur. Ayrıca, iş̧̧i haklarının sınırlarının hukuksal çerçevede yeniden ele alınması elzemdir. Çünkü günümüzde emeğin yok sayılması, sadece seks iş̧̧ilerine özgü bir olgu değildir. Sistematik bir biçimde göz ardı edilse bile, emek emek olmaktan çıkmaz.

Eve Sığmayan Hayatlar belgeselinde öznelerin kendi ses ve görüntüleriyle temsil edilemeyişi güvencesizliği daha da vurgularken, Pandemide Seks İş̧ileri belgeseli öznelerle seyirciyi bizzat karşılaştırır. Böylece yok sayılan ve görünmez kılınan hayatları görmemize ve duymamıza vesile olur. Her iki belgesel de, güvencesizliği ve kırılganlığı politik bir zeminde düşünmemize olanak sağladığı gibi yaralanabilir durumdaki anonim ötekilerle kurulan bağ|ılığın da her durumda vurgulanması gerektiğinin altını çizer. Sanatın pandemi koşullarında üretimi, emeği suiistimal edilen insanların deneyimlerine ses vermek için gereklidir. Her iki belgesel de, bu açıdan emeğin görünür kılınmasına ve eşitlenme üzerine sözler söylenmesine olanak sağlamıştır.

Bu belgesellerin de önerdiği üzere, günümüz dünyasında çalışmak orta - alt sınıf için hayatta kalmakla eşit hale gelmiştir. Bu nedenle, hayatta kalması daha zor olan dezavantajlı kesimlerin, yaralanabilirlik ve güvencesizlikleri en azından sorgulanmalıdır. Çünkü Butler'ın da belirttiği gibi, "[y]aralanmış olmak demek, insanın yara üzerine düşünme, hangi mekanizmalar aracılığıyla paylaştırıldığını öğrenme, başka kimlerin hangi şekillerde geçirgen sınırlardan, beklenmedik şiddetten, mülksüzleştirilmeden ve korkudan mustarip olduğunu anlama şansını elde etmesi demektir" (2005, s. 10). En nihayetinde; kırılganlıklarımız, yaralanabilirliklerimiz ve güvencesizliklerimiz bizi hem içinden geçtiğimiz salgın döneminde hem de gelecekte birbirimize bağlayabilecek midir?

\section{ORCID ID}

KAAN AKIN

(iD) https://orcid.org/0000-0002-3578-6205

ÇAĞDAŞ DUMAN

(iD) https://orcid.org/0000-0002-8330-2965 


\section{Declaration of Conflicting Interests}

The author declared that there were no conflicts of interest with respect to the authorship or the publication of this article.

\section{Çıkar Çatışması Beyanı}

Yazar bu makalenin yazarlık veya yayımlanmasına ilişkin olarak hiçbir çıkar çatışması olmadığını beyan etmiştir.

\section{KAYNAKÇA}

Adalı, A. \& Işıl, V. (Yönetmenler). (2020). Pandemide Seks Iş̧̧ileri [Film]. İstanbul: Kırmızı Şemsiye.

Alpman, P. (2016). Esmer Yakalılar: Kent-Sınıf-Kimlik ve Kürt Emeği. İstanbul: İletişim.

Bardan A. (2013). The New European Cinema of Precarity: A Transnational Perspective. E. Mazierska (Ed.), Work in Cinema içinde (69 - 90). Palgrave Macmillan, New York.

Berlant, L. (2011). Cruel Optimism. Durham, NC: Duke University Press.

Bora, T. (2010). Tekel Direnişinde Ara Son - Sınıf Mücadelesi: “Hep" Olan ve "Yeni" Olan. Birikim (251-252), 9 - 12.

Breman, J. (2013) A Bogus Concept. New Left Review (84), 130 - 138.

Butler, J. (2005). Kırılgan Hayat. (B. Ertür, Çev.) İstanbul: Metis Yayınevi.

Butler, J. (2015). Savaş Tertipleri. (Ş. Öztürk, Çev.) İstanbul: Yapı Kredi Yayınları.

Casas-Cortes, M. (2014). A Genealogy of Precarity, Rethinking Marxism, 26(2), 206 - 226. doi: 10.1080/08935696.2014.888849

Çolak, E. (2016). Akademide Güvencesiz Çalışma: Araştırma Görevlilerinin Deneyimleri. ViraVerita E-Dergi, (2) , 23 - 44.

Delacey, H. (2020). The Precarisation of Sex Workers During the COVID-19 Pandemic. https://www.leidenlawblog.nl/articles/the-precarisation-of-sex-workers-during-thecovid-19-pandemic. Erişim tarihi: 31.01.2021

Demirkaya, E. (2017). Prekarlık ve Prekarite Tartışmalarına Kısa Bir Giriş. Cogito (87), 6 - 23.

Engin, C. (2018). Sex Work in Turkey: Experiences of Transwomen. L. Nuttbrock (Ed.), Transgender Sex Work and Society içinde (196 - 213). New York: Harrington Park Press.

Frase, P. (2013). The Precariat: A Class or a Condition?, New Labor Forum (10), 1 - 4.

Güler, E. (2020). Trans Sex Workers' Collective Struggle in Urban Turkey. [Blog Post]. Retrieved from http://www.focaalblog.com/tag/sex-work/ 
Koç, F. (2012). İşçileşme Sürecinin Kürt Segmenti veya Kürt İşçilik Sorunu. Ö. Göztepe (Ed.), Güvencesizleştirme: Süreç, Yanılgı, Olanak içinde (147 - 158). Ankara: Notabene.

Koyama, E. (2013). Transfeminist Manifesto. S. Yardımcı, \& Ö. Güçlü (Ed.), Queer Tahayyül içinde (363 - 372). İstanbul: Sel.

Kutlu, D. (2012). Türkiye İşgücü Piyasasında Güncel Gelişmeler ve Güvencesizleşme Örüntüleri. Ö. Göztepe (Ed.), Güvencesizleştirme: Süreç, Yanılgı, Olanak içinde (61116). Ankara: Notabene.

Lorey, I. (2015). State of Insecurity: Government of the Precarious. (A. Derieg, Çev.) New York: Verso Futures.

Oğuz, ş. (2014). Tekel Direnişinin Işığında Güvencesiz Çalışma / Yaşama: Proletaryadan "Prekarya"ya mı?, Mülkiye Dergisi, 35 (271), 7 - 24.

Rev, N. \& Geist, F. M. (2017). Staging the Trans Sex Worker. Transgender Studies Quarterly, 4 (1), 112-127. https://doi.org/10.1215/23289252-3711577

Sanders, T. \& K. Hardy. (2013). Sex Work: The Ultimate Precarious Labour?, Criminal Justice Matters 93(1), $16-17$.

Standing, G. (2017). Prekarya Bildirgesi: Hakların Kısılmasından Yurttaşlığa. (S. Demiralp, Çev.) İstanbul: İletişim.

Standing. G. (2011). The Precariat: The New Dangerous Class. Bodmin, Cornwall: Bloomsbury Academic.

Seymour, R. (2012). We are All Precarious: On the Concept of the "Precariat" and its Misuses. New Left Project, (10), Retrieved from http://www.newleftproject.org/index.php/site/article comments/we are all precari ous on the concept of the precariat and its misuses

Smith, N. (2015). Queer in/and Sexual Economies. M. Laing, K. Pilcher, \& Nicola Smith (Ed.), Queer Sex Work içinde (13 - 22). Abingdon: Routledge.

Şenses, N. (2017). Rethinking Migration in the Context of Precarity: The Case of Turkey. C.U. Schierup, M.B. Jorgensen (Ed.), Politics of Precarity: Migrant Conditions, Struggles and Experiences içinde $(99-117)$. Leiden, The Netherlands: Brill.

Telek, A. (2020). Artık Hepimiz Prekaryayız: Tehlikeli ve Umutlu Gelecek. Ankara: NotaBene.

Yıldız, S. (Yönetmen). (2020). Eve Sığmayan Hayatlar [Film]. İstanbul.

Zengin, A. (2011). Iktidarın Mahremiyeti. İstanbul: Metis. 


\section{Sonnotlar}

'Filme linkten erişilebilir: https://www.youtube.com/watch?v=s8WhIH8OE7s\&ab channel=36-42Belgesel
ii Bedenleri ile cinsiyet kimlikleri uyumlu olan cis bireylerin kurduğu düzene dikkat çekmek için Ingilizce'de
kullanılan cis ve system kelimelerinin birleşimi.
iii Filme linkten erişilebilir: https://www.youtube.com/watch?v=IM-
EncM0elk\&ab channel=K\%C4\%B1rm\%C4\%B1z\%C4\%B1\%C5\%9EemsiyeDerne\%C4\%9Fi\%2FRedUmbrellaAssociati
on 